\title{
The declining role of interstate cigarette smuggling in the United States
}

\author{
Robert Kleine
}

In recent years the tobacco industry in the US has claimed that state cigarette tax increases would result in substantial cross-border smuggling. For example, during the campaign for a referendum which raised the state's cigarette excise tax by 25 cents per pack in Massachusetts last year, the Committee Against Unfair Taxes (supported heavily by the tobacco industry) claimed that the tax increase "will result in an estimated $14 \%$ decrease in cigarette sales by driving consumers across the border into neighboring states to purchase cigarettes and other goods". ${ }^{1}$ Similarly, the tobacco industry made the spectre of bootlegging and associated crime a major theme in its efforts to defeat California's Proposition 99 in 1988 (see figure).

Previous research has indicated that cigarette smuggling has become much less pervasive since the 1970 s, and that what smuggling remains is largely casual rather than organised. The Advisory Commission on Intergovernmental Relations (ACIR) published two detailed studies on cigarette smuggling in 1977 and $1985 .^{2,3}$ The second report estimated that the amount of cigarette revenue lost by the states because of smuggling had declined by $45 \%$ from 1975 to 1983 . In addition, an estimated $70 \%$ of the lost revenue resulted from the tax exemption for sales on Indian reservations and military bases, which encourages illegal sales. The ACIR concluded that the decline in cigarette tax evasion was due mainly to the enactment of the Federal Cigarette Contraband Act in 1978. My discussions with state tax officials indicate that the situation has not changed materially since the 1985 ACIR study. Some simple calculations support that conclusion.

\section{State price elasticity estimates}

Price elasticity (in the case of cigarettes) is defined as the percentage change in the quantity of cigarettes sold divided by the percentage change in price. An elasticity of -0.4 , for example, means that a $10 \%$ increase (decrease) in price would reduce (increase) by $4 \%$ the quantity of cigarettes sold. When the cigarette price increases in a given state, legal sales within the state can go down for two reasons: 1) smokers may buy fewer cigarettes, and/or 2) smokers may buy out-of-state cigarettes. As either of these effects becomes stronger, the numerator of the price elasticity equation increases, thereby increasing the

price elasticity estimate. In other words,

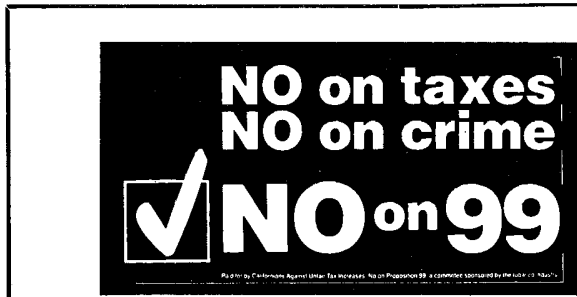

Figure 1 This sticker was produced during the 1988 campaign to pass Proposition 99, a state-wide referendum in California which raised the state's cigarette excise tax from 10 to 35 cents per pack. The small print on the sticker states, "Paid for by Californians Against Unfair Tax Increases/No on Proposition 99/a committee sponsored by the tobacco industry." The reference to crime on the sticker reflects a major theme of the industry in its $\$ 21$ million effort to defeat Prop. 99, namely, that the tax increase would lead to massive crime associated with interstate cigarette smuggling. Of course that never happened. (Sticker provided courtesy of Fulia Carol, Americans for Nonsmokers' Rights) - ED

cigarette bootlegging tends to inflate the elasticity of a high-tax state artificially. As a result, widespread interstate bootlegging should increase the range of state price elasticity estimates.

Table 1 shows "price elasticity" estimates for the US and selected states based on 1985-91 data from the Tobacco Institute (TI). ${ }^{4}$ True price elasticities are usually calculated after adjusting for inflation and taking into account other variables that may affect demand. The calculations in table 1 do not do so but are sufficient to examine the range of state "price elasticities". These calculations yield an "elasticity" of -0.32 for the US. Note that this figure is not affected by interstate smuggling, which is not a factor when national data are used, but it would be affected by smuggling from or to other nations.

Table 1 includes "elasticity" estimates for 10 states that have raised cigarette taxes by large increments since 1985 and three states that did not increase their cigarette taxes from 1985-91. The state "elasticity" figures, which do reflect cross-border smuggling, are remarkably consistent, ranging from -0.20 in Iowa (this number is suspect as the TI data indicate a $2.9 \%$ increase in consumption from 1989 to 1991) to -0.45 in Texas. They are also not substantially different from the figure calculated for the US as a whole. If interstate smuggling were widespread, a greater range of state "elasticity" figures would be expected.
Public Sector Knapp's Center Sq., Suite 401 48933-2134, USA

Mr Kleine is Vice President and Senior Economist at Public Sector Consultants. H and 1985 reports on cigarett bootlegging published by the Advisory Commission on Intergovernmental Relations, which are cited in this article. 
Table 1 Cigarette "price elasticity" estimates for selected states and the total US, 1985-91

\begin{tabular}{|c|c|c|c|c|c|c|c|c|c|}
\hline & \multirow{2}{*}{\multicolumn{2}{|c|}{ State tax ${ }^{\star}$}} & \multicolumn{3}{|c|}{ Retail price ${ }^{\star}$} & \multicolumn{3}{|c|}{ Per capital sales (packs) } & \multirow{3}{*}{$\begin{array}{c}\text { "Price } \\
\text { elasticity" }\end{array}$} \\
\hline & & & & & Percentage & & & Percentage & \\
\hline & 1985 & 1991 & 1985 & 1991 & change $e^{\star \star}$ & 1985 & 1991 & change & \\
\hline & \multicolumn{9}{|c|}{ States with large tax increases } \\
\hline & & & $\$$ & $\$$ & & & & & $\%$ \\
\hline California & 10 & 35 & 0.98 & 1.87 & 90.8 & 102.8 & 68.7 & -33.2 & -0.37 \\
\hline Connecticut & 26 & 40 & 1.19 & 1.76 & 48.1 & 111.0 & 86.7 & -21.9 & -0.46 \\
\hline Florida & 21 & 33.9 & 1.04 & 1.75 & 68.3 & 124.2 & 98.2 & -20.9 & -0.31 \\
\hline Illinois & 12 & 30 & 0.97 & 1.54 & 59.3 & 121.6 & 96.1 & -21.0 & -0.35 \\
\hline Iowa & 18 & 36 & 1.00 & 1.55 & 56.2 & 109.4 & 97.1 & -11.2 & -0.20 \\
\hline Minnesota & 18 & 38 & 1.02 & 1.74 & 71.3 & 113.0 & 86.2 & -23.7 & -0.33 \\
\hline New Jersey & 25 & 40 & $\begin{array}{l}1.02 \\
1.05\end{array}$ & 1.80 & 72.3 & 116.9 & 86.7 & -15.8 & -0.36 \\
\hline New York & 21 & 39 & 1.06 & 1.80 & 69.8 & 115.9 & 86.4 & -25.5 & -0.36 \\
\hline Rhode Island & 23 & 37 & 1.00 & 1.70 & 70.3 & 133.4 & 103.6 & -22.3 & -0.32 \\
\hline \multirow[t]{2}{*}{ Texas } & 19.5 & 41 & 1.02 & 1.74 & 70.2 & 115.9 & 79.4 & -31.5 & -0.45 \\
\hline & \multicolumn{9}{|c|}{ States with no tax increase } \\
\hline Georgia & 12 & 12 & 0.91 & 1.38 & 52.1 & 128.8 & 109.6 & -14.9 & -0.29 \\
\hline Massachusetts & 26 & 26 & 1.08 & 1.63 & 50.8 & 117.2 & 93.5 & -20.2 & -0.40 \\
\hline Virginia & 25 & 25 & 0.84 & 1.37 & 62.5 & 134.6 & 109.1 & -18.9 & -0.30 \\
\hline Total US & 15.9 & 25.9 & 0.98 & 1.53 & 56.1 & 122.0 & 100.4 & -17.7 & -0.32 \\
\hline
\end{tabular}

$\star$ Per pack of 20 cigarettes in cents.

$\star \star$ The national consumer price index (all items) increased by $26.6 \%$ from 1985 to 1991 . Therefore, all the price changes shown in this column exceed those due to inflation.

t.

$\therefore \quad$ Table 2 Variance in state cigarette sales per capita (packs) from US average: 1975, 1984, 1988, 1991 (below US average = "_")

\begin{tabular}{|c|c|c|c|c|c|}
\hline & State & 1975 & 1984 & 1988 & 1991 \\
\hline \multirow[t]{2}{*}{$=$} & Alabama & -19.2 & -9.8 & -0.8 & 7.5 \\
\hline & Alaska & 19.5 & 36.1 & -32.9 & 1.4 \\
\hline \multirow[t]{3}{*}{$*$} & Arizona & -9.1 & -6.3 & -10.7 & -19.2 \\
\hline & Arkansas & -16.1 & -1.6 & 8.6 & 16.4 \\
\hline & California & -3.8 & -18.4 & -22.8 & -31.7 \\
\hline \multirow[t]{2}{*}{$=$} & Colorado & 0.1 & -1.2 & -18.3 & -10.2 \\
\hline & Connecticut & -20.7 & -16.0 & -8.1 & -13.7 \\
\hline \multirow[t]{2}{*}{4} & Delaware & 16.7 & 21.5 & 24.2 & 18.4 \\
\hline & District of Columbia & 45.6 & -2.4 & -7.5 & -18.2 \\
\hline & Florida & 1.0 & 7.4 & 6.6 & -2.2 \\
\hline \multirow[t]{2}{*}{-1} & Georgia & -8.0 & 5.2 & $\begin{array}{r}0.0 \\
11.2\end{array}$ & 9.2 \\
\hline & Hawaii & -38.5 & -41.7 & -57.3 & -45.7 \\
\hline \multirow[t]{3}{*}{$i$} & Idaho & -7.6 & -14.7 & -28.4 & -15.0 \\
\hline & Illinois & 0.9 & -3.6 & -5.3 & -4.3 \\
\hline & Indiana & 31.5 & 10.4 & 21.1 & 26.8 \\
\hline \multirow[t]{2}{*}{ 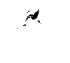 } & Iowa & -10.4 & -17.8 & -12.7 & -3.3 \\
\hline & Kansas & -7.5 & 1.9 & -9.7 & -8.6 \\
\hline \multirow{3}{*}{$3 \ldots$} & Kentucky & 92.1 & 71.4 & 60.3 & 70.4 \\
\hline & Louisiana & 2.7 & 2.1 & -2.0 & 6.8 \\
\hline & Maine & 9.8 & 4.9 & 12.1 & -6.9 \\
\hline \multirow[t]{3}{*}{$\cdot$} & Maryland & 15.2 & -0.3 & 2.1 & -2.8 \\
\hline & Massachusetts & -4.8 & -10.4 & -1.2 & -6.9 \\
\hline & Michigan & 5.9 & -4.3 & 8.2 & 9.9 \\
\hline \multirow[t]{2}{*}{$\therefore$} & Minnesota & -19.4 & -19.6 & -18.8 & -14.2 \\
\hline & Mississippi & -14.1 & -8.4 & -3.9 & -14.2 \\
\hline \multirow[t]{3}{*}{ 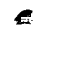 } & Missouri & 4.6 & 2.1 & 14.5 & 19.5 \\
\hline & Montana & -7.1 & 2.0 & -25.8 & -17.5 \\
\hline & Nebraska & -16.8 & -16.1 & -20.0 & -8.0 \\
\hline \multirow[t]{2}{*}{$=$} & Nevada & 74.3 & 39.3 & 29.0 & 15.1 \\
\hline & New Hampshire & 138.2 & 104.7 & 67.5 & 44.4 \\
\hline \multirow[t]{3}{*}{$a$} & New Jersey & -8.6 & -9.2 & -5.1 & -13.7 \\
\hline & New Mexico & -27.8 & -20.5 & -35.2 & -30.5 \\
\hline & New York & -7.0 & -7.5 & -6.7 & -14.0 \\
\hline \multirow[t]{2}{*}{ 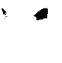 } & North Carolina & 95.1 & 38.6 & 33.1 & 32.3 \\
\hline & North Dakota & -13.0 & -7.8 & -25.8 & -15.2 \\
\hline & Ohio & -8.4 & -3.9 & 9.5 & 12.8 \\
\hline \multirow{2}{*}{$\neq$} & Oklahoma & 2.0 & 15.1 & -9.3 & -12.6 \\
\hline & Oregon & 23.5 & -0.3 & -4.7 & -0.3 \\
\hline \multirow{3}{*}{$\therefore \Delta$} & Pennsylvania & -16.3 & -6.7 & -5.3 & 2.1 \\
\hline & Rhode Island & 23.8 & 8.0 & 25.1 & 3.2 \\
\hline & South Carolina & -0.4 & 3.0 & 11.5 & 21.1 \\
\hline \multirow{2}{*}{2} & South Dakota & -17.4 & -20.5 & -21.0 & -8.6 \\
\hline & Tennessee & -13.5 & -3.3 & 12.4 & 20.2 \\
\hline \multirow[t]{3}{*}{$\Rightarrow 2$} & Texas & -14.9 & -0.5 & -16.4 & -20.8 \\
\hline & Utah & -55.1 & -62.4 & -57.9 & -46.9 \\
\hline & Vermont & 24.6 & 20.7 & 15.8 & 20.5 \\
\hline-2 & Virginia & 21.8 & 24.3 & 16.6 & 8.7 \\
\hline & Washington & -13.4 & -16.6 & -24.7 & -21.7 \\
\hline & West Virginia & -7.7 & -17.5 & -3.8 & -0.3 \\
\hline a & Wisconsin & -17.4 & -22.8 & -10.3 & -4.9 \\
\hline & Wyoming & 29.8 & 10.4 & 1.4 & 8.7 \\
\hline$\approx$ & $\begin{array}{l}\text { All States/per capita sales } \\
\text { (weighted average) }\end{array}$ & 130.90 & 122.7 & 112.9 & 100.4 \\
\hline 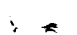 & Coefficient of variation & 8.56 & 4.26 & 4.96 & 4.33 \\
\hline
\end{tabular}

An interesting state to focus on is Massachusetts where, as noted above, voters recently approved a 25-cent-per-pack increase in the cigarette tax. The calculation for Massa- chusetts indicates an "elasticity" of -0.40 , which is near the upper end of the range, probably due to the easy access Massachusetts smokers have to lower-priced cigarettes in New Hampshire. It is worth noting that from 1977 to 1983, cigarette consumption in Massachusetts increased $0.8 \%$ despite a $55 \%$ increase in the retail price of cigarettes. During that period the cigarette tax was 21 cents per pack in Massachusetts and 12 cents per pack in New Hampshire, and the retail price was, on average, 21.3 percent higher in Massachusetts. In 1991 the retail price of cigarettes was $6 \%$ higher in Massachusetts than in New Hampshire, and a 25-cent increase in Massachusetts would have pushed the price disadvantage to $22 \%$, nearly the same level as in the 1977-83 period. This suggests that the increase in the Massachusetts cigarette tax may not reduce consumption as much as opponents have claimed.

\section{Variance in state cigarette sales per capita}

Table 2 lists the variance in states' per capita cigarette sales from the national average for each of the years noted. A number of factors explain variations between states. Among these factors are price (including state and local taxes), income, religion, ethnic population, region, tourism, demographics, and crossborder smuggling. The data in table 2 show that the variation nationwide declined from 8.56 packs per capita in 1975 to 4.26 packs in 1984 , then rose to 4.96 packs in 1988 before declining to 4.33 packs in 1991 . It is unlikely that there were major relative changes in any of the factors listed above, other than price and smuggling. This leads one to conclude that there has been little, if any, increase in smuggling since 1984.

Table 2 provides additional evidence to support this conclusion. Since 1984, consumption in the major supplier states of Kentucky, North Carolina, and Virginia (which have the lowest tax rates) has moved closer to the US 
average. For example, in 1984 per capita consumption in North Carolina exceeded the US average by 38.6 packs while in 1991 per capita consumption exceeded the US average by only 32.3 packs. This is persuasive evidence that the level of smuggling has not increased in recent years.

My conclusion is that a 25 -cent increase in the typical state's cigarette tax, about a $14 \%$ increase in the retail price of cigarettes, would reduce consumption by no more than $4 \%$ to $6 \%$. This conclusion assumes a price elasticity of -0.30 to -0.40 . The likely loss would be somewhat larger in states where large popu- lations are concentrated near the border with states that levy considerably lower cigarette taxes. However, states need no longer fear that differential tax rates will result in the large smuggling activity that flourished in the 1970 s.

1 Facts about cross-border sales. Boston, Massachusetts Committee Against Unfair Taxes, 1992.

2 Advisory Commission on Intergovernmental Relations. Cigarette bootlegging : a state AND federal responsibility. Washington, DC: ACIR, 1977.

3 Advisory Commission on Intergovernmental Relations. Cigarette tax evasion: a second look. Washington, DC: ACIR, 1985.

4 Tobacco Institute. The tax burden on tobacco: historical compilation, 1991. Vol 26, Washington, DC: Tobacco Institute, 1992 